\title{
LATGALES APTIEKU SĀKOTNE
}

Latvijas aptieku vēstures kopainā visbālāk ir iezīmēta Latgalē. Ja par Vidzemes un Kurzemes aptiekām un aptiekāriem rūpīgus un pamatīgus pētijjumus jau 20. gs. sākumā ir veikuši Erihs Zeiberlihs (1882-1946) ${ }^{1}$, Gustavs Otto (1843-1917)2 , Frīdrihs Lihingers (1864-1931) $)^{3}$ un daži citi, tad par Latgales aptiekām līdzvērtīgi sistemātiski pētijumi līdz Šim vēl nav ne veikti, ne arī sākti. Grūtỉbas saistāmas ne tik daudz ar novada vēsturiski izveidojušos un tradicionālo atš̌kirtību no pārējās Latvijas teritorijas, cik ar pētnieku vai vinuu ieinteresētỉbas trūkumu un vēl vairāk - ar avotpētnieciskās bāzes nepietiekamu apguvi, sarežgìtu pieejamỉbu un it bieži arī ar tâs zudumu.

Šai rakstā galvenokārt apkopoti dati, kas aizgūti no Krievijas, Baltkrievijas un Latvijas arhīviem, sastatot tos ar publicētiem dažāda veida pārskatiem un sarakstiem, kā arī ar visai pieticīgām ziṇām pētnieciskajā un biogrāfiskajā literatūrā. Hronologiski aptverts laikposms līdz Pirmajam pasaules karam, bet konkrēts aptieku darbības sākums jeb datējums, proti, kad radās vai kad dokumentos pirmoreiz minēta aptieka Latgalē, pagaidām paliek neatrisināta jautājuma līmenī.

Tālab mēgināts vākt datus, kas attiecināmi jau uz Krievijas impērijas laikmetu un kuri Sanktpēterburgas un Minskas arhīvos bija atrodami, proti, pēc Latgales pievienošanas impērijai 1772. gadā Polijas pirmās dalī̌sanas rezultātā, bet it īpaši pēc 1802. gada, kad novads administratīvi teritoriālā ziṇā tika noformēts trīs Vitebskas guberṇas rietumda|as aprinḳu veidā - Daugavpils, Ludzas un Rēzeknes apriṇkisis, un kad dažādi dati atskaišu veidā biežāk klūst sastopami arhīvos saglabātā dokumentâcijā.

1 Seuberlich E. Liv- und Estlands älteste Apotheken // Sitzungsberichte der Gesellschaft für Geschichte und Altertumskunde der Ostseeprovinzen Russlands aus dem Jahre 1911. - Riga, 1912. - S. 39-164; .. aus dem Jahre 1912. - Riga, 1914. - S. 205-345.

2 Otto G. Die Apotheken und Apotheker Kurlands // Sitzungsberichte der Kurländischen Gesellschaft für Literatur und Kunst aus dem Jahre 1914. - Mitau, 1915. - S. 81-213.

3 Lichinger $F$. Aus Russlands pharmazeutischer Vergangenheit. - Riga, 1927. - 433 S.; Lichinger F. Die Geschichte der Pharmazeutischen Gesellschaft zu Riga. - Riga, 1903. $-104 \mathrm{~S}$. 
Pẽc analogijas un velkot paralēles ar kaiminnovadiem, varētu spriest, ka aptieka Latgales lielākajā pilsētā Daugavpilī ir ierîkota vismaz 18. gs., bet ticamāk - vēl agrāk. Vismaz netieši to apliecina dati, ka citās lielākās Latvijas pilsētās aptiekas ir radušãs jau 17. gs. un pat 16. gs., bet visagrāk Rīgā, - 14. gs. Ar 16. un 17. gs. ir datētas arī pirmās aptiekas Baltkrievija $\bar{a}^{4}$ un Lietuvāa ${ }^{5}$. Daugavpils plašo un vērtīgo arhīvu 1795. gadā nodedzināja pilsētā iebrukusī konfederātu vienība kṇaza M. Ogiṇska vadỉiā ${ }^{6}$, taču vajadzētu būt kādiem citiem, vēl neapzinātiem avotiem. Gan gluži drošu un vēlīnu norādi, ka Daugavpilī 1798. gadā patiešām ir darbojusies aptieka, izdevās atrast Baltkrievijas gubernas Ārstniecības pārvaldes dokumentos ${ }^{7}$. Taču kopumā Latgales aptieku agrīnais posms vẽl meklējams vēstures avotos.

Līdzīgs apliecinājums rodams pēdējā laikā publicētos novadpētnieciskos meklējumos par Krāslavu, kas 18. gs. bija diezgan ievērojams tirdzniecỉbas, kultūras un garīgās dz̄ives centrs. Grāfam J. L. Plāteram 1729. gadā nopērkot miestinu, tajā bija 47 ēkas ${ }^{8}$. Piejaujot, ka vienā no tầm ir atradusies aptieka, proti, tās līdz mūsu dienām saglabājusies èka, pēc arhitektonisku detalu izpētes tiek secināts, ka tâ varētu būt celta laikā no 1710. līdz 1713. gadam. To apliecinot arī telpu plānojums: zālu gatavošana un tirdzniecỉba norisusi pirmajā stāvā, augšstầvā bijis aptiekāra dzīvoklis, êrti izbūvētā pagrabā - noliktava. Baroka stilā celtās ēkas fasādi greznojis kolonnās balstîts balkons, kas vairs nav saglabājies, turklāt laika zobs stipri skāris arī iekštelpas ${ }^{9}$. Kritiskāk izvērtējot, (1) iedomātais laiks celtniecỉbai bija īpaši nelabvēlīgs sakarā ar Zieme|lu kara un Lielā mēra izraisīto postu, (2) Krāslavas uzplaukums un plasāaa celtniecỉba sākās vêlāk, Plāteru laikā, un (3) tā varēja būt parasta tirgotāja māja, ko vêlāk nebija grūti pielāgot aptiekas specifikai. Taču netieši noprotams, ka aptieka šai êkā tomēr ir atradusies jau pirms Krāslavas žēlsirdīgo māsu kopienas slimnīcas uzcelšanas ${ }^{10}$, proti, pirms 1789. gada.

Gluži konkrēti un precīzi dati par Krāslavas aptiekas darbību ir kopš 1813. gada, kad par tâs īpašnieku k|uva ienācējs no Prūsijas provizors Martins Bonins, kas pirms tam no 1808. gada bija strādājis Jēkabpilî̉ ${ }^{11}$. Turklāt Krăslavas Vēstures un

4 Грицкевич В. П. С факелом Гиппократа: Из истории белорусской медицины. Минск, 1987. - С. 64-68; Крючок Г. Р. Очерки истории медицины Белоруссии. - Минск, 1976. - С. 63,64 .

5 Мицельмахерис В. Г. Очерки по истории медицины в Литве. - Ленинград, 1967. - C. $60-65$.

6 Сапунов А. Инфлянты. - Витебск, 1886. - С. 27.

7 Baltkrievijas Valsts vẽstures arhīvs Minskā (BVVA), 3224. f., 1. apr., 10. 1., 31. lp.

8 Broel-Plater L. Krasław. - Londyn, 1975. - Str. 8.

9 Stepina E. Zem baroka stila velvēm // Materia Medica. - 2000. - 7. nr., - 23.,24. lpp.

10 Broel-Plater L. Krasław. - Londyn, 1975. - Str. 15.

11 Otto G. Die Apotheken und Apotheker Kurlands // Sitzungsberichte der Kurländischen Gesellschaft für Literatur und Kunst aus dem Jahre 1914. - Mitau, 1915. - S. 131. 


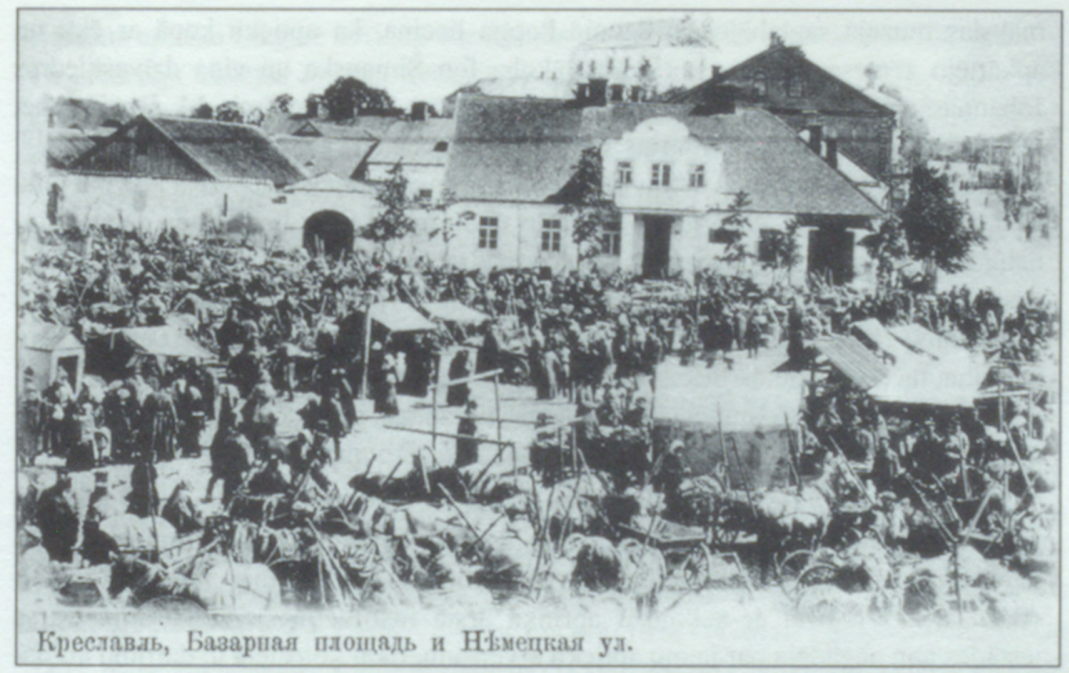

Krāslavas tirgus laukums 20. gs. sākumā ar aptiekas ēku augšêjā labajā stūrī

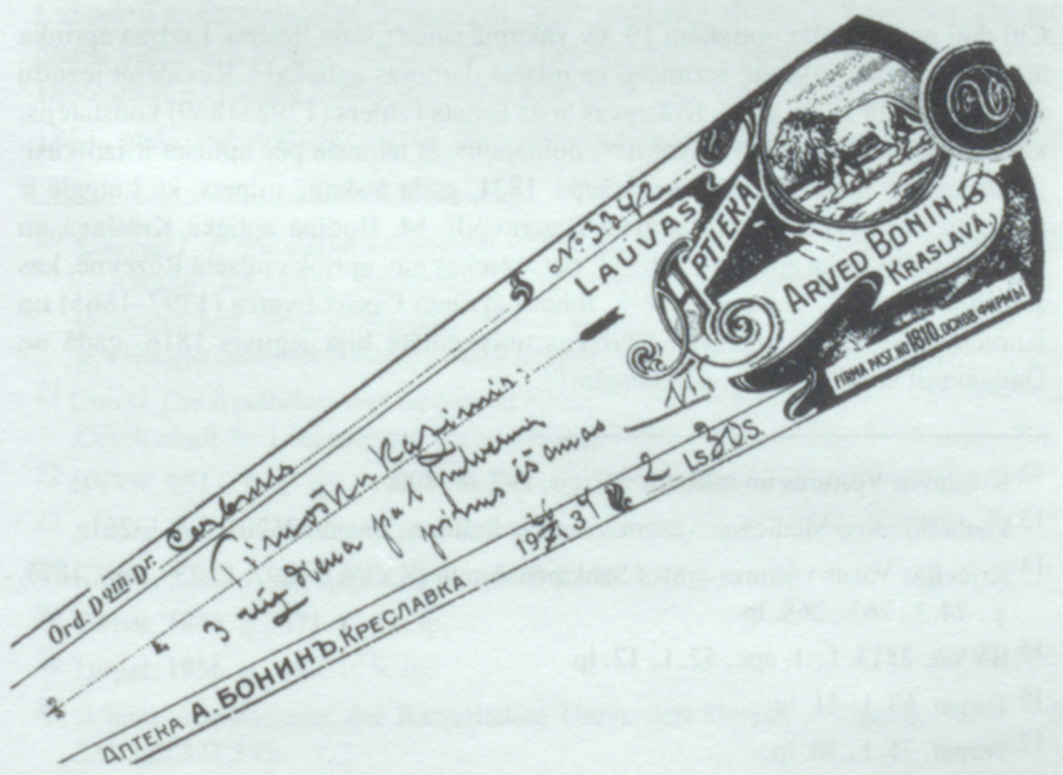

Krāslavas aptiekas 1934. gada signatūra, uz kuras redzams aptiekas dibināŠanas gadskaitlis - 1810 
mākslas muzejā saglabājusies līguma kopija liecina, ka aptieku kopā ar ēku un apkārtējo zemesgabalu no aptiekāra Jākoba fon Šimanska un vina dzīvesbiedres Johannas, dzim. Šmites, 1813. gadā par 10 tūkst. rubl̨u nopircis M. Bonins, bet Daugavpils aprinķa ārsts Martins Orlovskis apliecinājis viṇa aptiekāra tiesỉbas ${ }^{12}$. Boninu aptiekāru dinastijai đetrās paaudzēs Krāslavas aptieka piederēja līdz pat viṇu izcelošanai uz Vāciju 1939. gadā. Savukārt uz šīs aptiekas ar 1934. gadu datētas signatūras, kas glabājas Paula Stradiña Medicīnas vēstures muzejā, norādîts, ka "firma" pastāv no 1810. gada ${ }^{13}$. Varētu piejaut, ka vai nu J. fon Šimanskis aptieku ierīkojis (atjaunojis) 1810. gadā, vai arī M. Bonins šajā gadā uzsācis patstāvīgu darbību kaut kur citur, taču visticamāk liekas, ka 1810. gads signatūrā reklāmas pēc izvēlēts tālab, ka părprasts uz iepriekšminētā līguma augšã norādītais gadskaitlis, proti, 1813. gadā noslēgtā līguma teksts rakstīts uz 1810. gada t. s. gerboña veidlapas.

Tomēr arhīvos uzietie dati par Latgales aptieku darbību 19. gs. sākumā ir diezgan fragmentāri un vietām pretrunīgi. Aptiekas bija privātīpašums, valsts varas sistemātiskai kontrolei tika pakjautas pēc guberṇu Ārstniecības pārvalžu izveidošanas 1797. gadā ar sekojošu apriṇksa ārsta institūcijas iedibināšanu. Varas iestādes gan negādāja par jaunu aptieku atvêršanu, tikai kotrolēja to darbību atbilstīgi noteiktai kārtībai. Taču drīz vien sekoja Napoleona karagājiens 1812. gadā un tā izraisītie postījumi, kuru dē] aptieku darbība uz laiku tika apstādināta. Piemēram, Daugavpils aptieka savu darbību atjaunot spēja tikai 1819. gadā14.

Citi dati par Latgales aptiekām 19. gs. sākumā sniedz šādu liecību. Ludzas apriṇka ârsta 1818. gada atskaitē atzīmēts, ka pilsētā darbojas aptieka ${ }^{15}$. Revidējot jezuītu aptieku Izvaltā 1820. gadā, Krāslavas ārsts Ernsts Eihlers (1792-1869) konstatējis, ka tã atrodas nožêelojamā stāvoklī16; domājams, šĩ iemesla pễ aptieka ir iznîkusi, jo turpmākās atskaitēs vairs neparādās. 1821. gada atskaitē minēts, ka Latgalē ir trīs aptiekas: Ivana Everca aptieka Daugavpilī, M. Bonina aptieka Krāslavā un Ivana Romanovska aptieka Ludzā'17, bet aptiekas nav apriṇķa pilsētā Rēzeknē, kas atkārtots arī 1822. gada atskaitēe ${ }^{18}$. Johans (Ivans) Ulrihs Evercs (1797-1865) no Kurzemes provizora diplomu Têrbatas universitātē bija ieguvis 1816. gadā un Daugavpilī strādāja līdz mūža beigām ${ }^{19}$.

12 Krāslavas Vēstures un mākslas muzejs, DC, nr. 890.

13 Paula Stradina Medicīnas vēstures muzeja krājums, inv. nr. 26201, LA 13261.

${ }^{14}$ Krievijas Valsts vēstures arhīvs Sanktpēterburgā (KVVA), 1297. f., 239. apr., 1875. g., 74. 1., 267., 268. 1p.

15 BVVA, 2513. f., 1. apr., 52. 1., 12. Ip.

16 Turpat, 63. 1., 11. 1p.

17 Turpat, 75. 1., 30. Ip.

18 Turpat, 78. 1., 37. Ip.

19 Album Academicum der Kaiserlichen Universität Dorpat. - Dorpat, 1889. - S. 71. 
Nākamā aptieka Latgalē ierỉkota Varak|ānos un darbojusies jau vismaz 1828. gadā ${ }^{20}$. Tã piederēja vietējās muižas ĩpašniekam grāfam K. Borham. No 1840. līdz 1848. gadam Varak|ānu aptiekas pārvaldnieks bija Tērbatas universitātes audzēknis provizors Johans Grīneizens (1814-1882) no Piltenes, kas pēcāk nopirka aptieku Bauskā²1 .

Aptuveni tajā pašā laikā atvērta arī Ārensa aptieka Rēzeknē, jo, katrā ziṇā, tās eksistence apliecināta 1836. gada dokumentos ${ }^{22}$. Iespējams, ka dokumentos ir pretruna, jo Tērbatas universitātes akadēmiskais albums liecina, ka vidzemnieks Jākobs Ārenss (1790-1856) pēc provizora grāda iegūšanas 1820. gadā bijis aptiekas īpašnieks Ludzā, vēlāk - Disnā23 .

Tâdējādi Latgalē aptiekas bija trīs aprinkka pilsētās un vēl Krāslavā un Varak|ānos ${ }^{24}$. Vitebskas gubernas Ārstniecỉbas pārvaldes 1849. gada atskaitē minēti to īpašnieki: Daugavpilī - J. Evercs, Krāslavā - Aleksandrs Bonins, Ludzā - J. Ārenss, Rēzeknē Kārlis Lucavs, Varak|ānos (pārvaldnieks) - Johans Hāfenbergs ${ }^{25}$. 1856. gada atskaitē izmaiṇas fiksētas Ludzā - Sttofrēgens, kā arī Varak|ānos - Hāgemanis ${ }^{26}$. Paralēli dati par Têrbatas audzēknniem: A. Bonins bija iepriekšejjā īpašnieka M. Bonina dēls un provizora grādu ieguva 1836. gadā; Kārlis Vilhelms Lucavs (1814-1876) no Daugavpils diplomēts 1841. gadā; kurzemnieks Kārlis Štofrēgens (1819-1884) pēc provizora tiesỉbu iegū̌anas 1847. gadā strādājis Polockā, Ludzā, Drisā un atkal Polockā; Leopolds Hāgemanis no Vidzemes par provizoru kḷuvis 1849. gadā un no 1850. gada strādājis Varak|ānos ${ }^{27}$. Līdztekus Everca aptiekai Daugavpilī 1859. gadā tika atklāta otra aptieka, kas piederēja Samuilam Višñavskim, bet pēcāk 1865. gadā - Venjamina Natansona aptieka, 1866. gadā - Frīdriha Kades aptieka, 1870. gadā - Ecehiila Lunca aptieka ${ }^{28}$.

1864. gadā vai nedaudz agrāk tika atvērta Krauzes aptieka Krustpilīi29, kuras

${ }^{20}$ Крючок Г. Р. Развитие медицины и здравоохранения Белоруссии (конец XVIII - начало XX вв.): Диссертация на соискание ученой степени доктора медицинских наук. - Минск, 1964. - С. 152. [Manuskripts Latvijas Medicīnas akadēmijas bibliotēkā. Autors atsaucas uz KVVA, 1281. f., 11. apr., 20. 1., 97. Ip.]

${ }^{21}$ Otto G. Die Apotheken und Apotheker Kurlands // Sitzungsberichte der Kurländischen Gesellschaft für Literatur und Kunst aus dem Jahre 1914. - Mitau, 1915. - S. 150.

22 BVVA, 2513. f., 1. apr., 147. 1., 1. lp.

23 Album Academicum der Kaiserlichen Universität Dorpat. - Dorpat, 1889. - S. 97.

24 KVVA, 1297. f., 244. apr., 1844. g., 98. 1., 18. Ip.

25 Turpat, 1849. g., 371. 1., 21. lp.

26 Turpat, 1856. g., 689. 1., 9. 1p.

27 Album Academicum der Kaiserlichen Universität Dorpat. - Dorpat, 1889. - S. $231,302,322,355$.

${ }^{28}$ KVVA, 1297. f., 239. apr., 1875. g., 74. 1., 267.,268. Ip.

29 Turpat, 1864. g., 2. 1., 33. Ip. 
dibināšana diskutējama. Jelgavas ķirurga dēls Ādolfs Krauze (1812-1881), ieguvis provizora diplomu Tērbatā 1840. gadā, 1844. gadā nopirka Jēkabpils aptieku, kuras īpašnieks bija līdz 1877. gadam ${ }^{30}$. 1857. gadā, kad tika likts Krustpils slimnīcas pamatakmens, periodikā minēts, ka svinībās piedalījies vietējais ārsts un aptiekārs $^{31}$ (nenosaucot vārdu). Tỉk tiešăm, Jēkabpils aptiekai ir bijusi filiāle Krustpilī, kuru vadījis tas pats $\bar{A}$. Krauze. Taču 1866. gadā provizors Nikolajs Zakss Vitebskas gubernas Ārstniecỉbas pārvaldei lūdza ațaut atvērt normālaptieku filiālaptiekas vietā, jo pavasaros un rudeņos aptiekāram esot grūti nok|̣̄t pāri Daugavai no Jēkabpils Krustpilī, turklāt Krustpilī plaukstot rūpniecỉba, tirdzniecība, uzcelta dzelzce|a stacija un iedzīvotāju skaits sasniedzis sešus tūkstošus ${ }^{32}$. Ā. Krauzem no nevēlamā konkurenta izdevās atbrīvoties, taču 1876. gadā ațauju normālaptiekas ierīkošanai Krustpilī saņēma provizors Levi.

Līdzīgi notikumi risinājās Lĩvānos, kur filiālaptieku 1868. gadā bija ierikojis provizors Jasinskis, bet 1880. gadā to pārdevis provizoram Frīdriham Kadem. Aptiekāra palīgs Grigorijs Muds 1889. gadā lûdza aţauju Līvānos filiālaptiekas vietã atvêrt normālaptieku, turklāt F. Kades aptieka būtu jāslēdz. Neguvis atbalstu Vitebskā, G. Muds sūdzējās lekšlietu ministrijas Medicinas departamentā, kas tomēr nostājās F. Kades pusē, ațjaujot viṇam 1891. gadã filiālaptieku pārveidot par normālaptieku³3. Vairums Latgales aptieku tika atvērtas 19. gs. beiguposmã, it īpaši pēc 1881. gada, kad impērijā tika pieņemts likums par lauku aptiekām, kas paredzēja atvieglinājumus to darba kārtỉbā. 1889. gadā Daugavpils apriṇkī darbojâs 15, Ludzas -2, Rēzeknes apriṇḳ̄i - 4 aptiekas - tātad Latgalē kopumā - 21 aptieka ${ }^{34}$. Jaunas aptiekas tika atvērtas Gostinos - 1878. gadā, Preilos - 1880. gadā, Dagdā - 1882. gadā, Kărsavā un Višḳ̂os 1883. gadā, Vịānos - 1887. gadā, Vį̣akā - 1894. gadā, Balvos - 1899. gadā, utt. 1901. gadā Latgalē jau bija 27 aptiekas, no kurām 12 atradās apriṇḳa pilsētās ${ }^{35}$.

Tomēr jaunu aptieku atvēršanas process norisinājās ne tik raiti, kā to vēlētos nākamie īpašnieki. Lūgumu aṭaut atvērt aptieku Vị̣akā 1889. gadā iesniedza provizors Viktors Zīlings, taču tas tika noraidīts formāla iemesla pēc ${ }^{36}$, un aptiekas atvēršana

${ }^{30}$ Lichinger F. Die Geschichte der Pharmazeutischen Gesellschaft zu Riga. - Riga, 1903. - S. 60; Otto G. Die Apotheken und Apotheker Kurlands // Sitzungsberichte der Kurländischen Gesellschaft für Literatur und Kunst aus dem Jahre 1914. Mitau, 1915. - S. 165,166.

31 Purmall H. No Krīcburgas // Baznīcas Ziṇas. - 1857. - 12. nr.

32 LVVA, 658. f., 3. apr., 17. 1., 1. lp.

33 Turpat, 277. 1., 10., 30., 38. lp.

34 Памятная книжка Витебской губернии на 1889 год. - Витебск, 1889. - С. 262-267.

35 LVVA, 657. f., 1. apr., 28. 1., 22., 23. Ip.

36 Turpat, 658. f., 2. apr., 73. 1., 1., 10. Ip. 


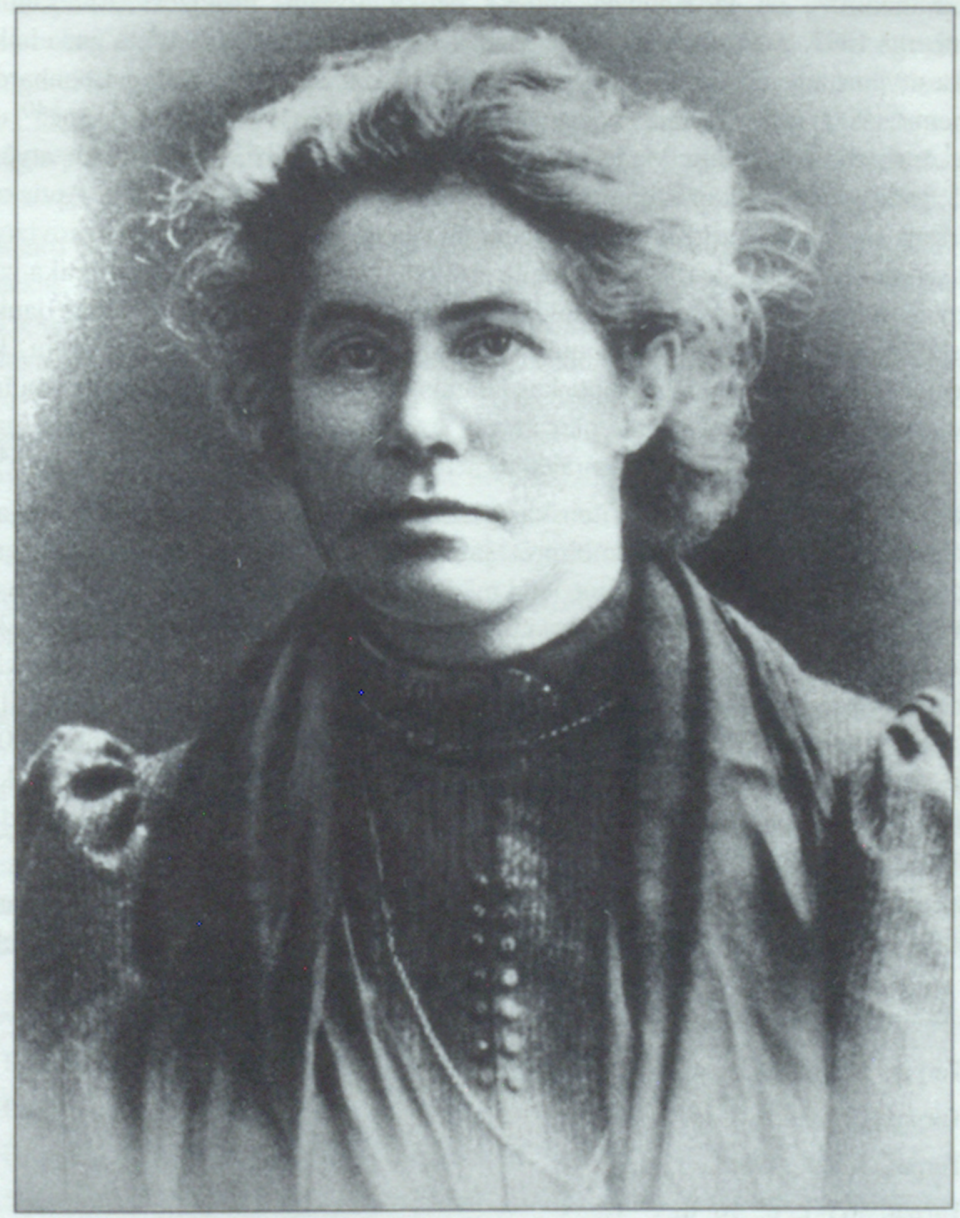

Stanislava Dovgjallo (1865-1933),

pirmā sieviete provizore Latvijā 
ieilga uz pieciem gadiem, to paveicot jau citam īpašniekam. Atłauju dibināt Kaunatas aptieku 1889. gadā sanēma tirgotājs Rafails Bobrovs, taču noteiktā viena gada laikā to nepaspēja izdarît, tâpēc ațjauja tika anulēta; līdzīga iemesla pēc 1892. gadā sañemtā ațauja 1894. gadā tika liegta aptiekāra palīgam Haimam Vilkomirskim ${ }^{37}$, un tā Kaunatā aptieka netika atvērta. Provizors Aleksandrs Ritenbergs 1897. gadā sanēma at|auju Maltas aptiekas ierīkošanai. Arī tā gada laikā netika atvērta, un at|auja anulēta ${ }^{38}$. Līdzīgi notika ar aptiekāra palīgu Leonhardu Zumentu 1900. gadā Kalupe $\bar{e}^{39}$, ārstu Jankelu Judeleviču 1905. gadā Asūnē ${ }^{40}$ un aptiekāra palīgu Nikolaju Madernieku 1910. gadā Bērzpilīi ${ }^{41}$ (tur aptieku atvēra 1915. gadā). Jādomā, ka tas bija saistîts ar iniciatoru nepietiekamu turību. Aptiekas atvēršana ievilcinājās arī Zilupē, kur vispirms at|jauju 1902. gadā sanēema provizors Aleksandrs Braže, bet, kad aptieka nebija ierīkota, 1903. gadā jauna aţauja tika izsniegta provizoram Edgaram Mērholdam ${ }^{42}$, kas to visbeidzot atvēra. Taču lauku aptieku apgrozījums bija neliels un ne vienmēr nodrošināja aptiekāra iztiku, ko apliecina tolaik vienīgās slēgtâs aptiekas liktenis Pasienē - īpašnieks aptiekāra palīgs Movša Gošteins aptieku centās pārcelt gan uz izdevīgāku vietu Vecslabadā, gan nodot rentniekiem, un tikai pēc vairākkārtējiem lūgumiem saṇēma atjauju to slēg $t^{43}$. Varas iestāžu, proti, vispirms Vitebskas guberņas pārvaldes Ārstniecības noda|as, kas izsniedza aţ̦auju, attieksme pret jaunu aptieku atvēršanu izpaudās gan sekošanā likumam, gan arī jaujot ietekmēties aptieku savstarpējās konkurences cīnā. Daugavpils provizoram Paulam Luncam ațauja ierīkot homeopātisko aptieku 1889. gadā tika liegta, jo vinam jau viena aptieka pilsētā esot, turklāt homeopātiskām aptiekām pastāvot īpaši noteikumi ${ }^{44}$. Skolotāja sievas Marijas Kalašņikovas lūgums aţ̧aut ierỉkot lauku aptieku vasaras sezonã Stropos 1901. gadā tika noraidīts tāpēc, ka tuvākā aptieka pilsētā atrodas mazāk nekā noteikto septiņu verstu attālumā ${ }^{45}$, kas gan vêlāk kādai no Daugavpils aptiekām neliedza Stropos ierīkot savu filiāli.

Konkurences cīna īpaši izpaudās Daugavpilī. Jau 1876. gadā vietêjā Ebreju slimnīca lūdza gubernas pārvaldes Ārstniecības nodalu at|̣aut ierỉkot pie slimnīcas aptieku

${ }^{37}$ Turpat, 1. apr., 91. 1., 4., 8., 18., 26. lp.

38 Turpat, 121. 1., 5., 8. lp.

39 Turpat, 3. apr., 399. 1., 3., 6. lp.

40 Turpat, 563. I., 6., 10. Ip.

41 Turpat, 2. apr., 168. 1., 11., 16. 1p.

42 Turpat, 118. 1., 17., 32. Ip.

43 Turpat, 112. 1., 56., 122. Ip.

44 Turpat, 3. apr., 284. I., 1., 2. lp.

45 Turpat, 419. 1, 1., 6. lp. 
trūcīgiem cilvēkiem, taču Daugavpils aptiekāru pretdarbības dē] lūgums tika atteikts ${ }^{46}$. Līdzīgi humānismā argumentēti lūgumi tika atraidīti arī 1880. un 1892. gadā ${ }^{47}$. Bet vislielākais troksnis tika sacelts 1899. un 1900. gadā, kad, līdztekus ar Ebreju slimnīcu, lūgumu aţ̧aut atvērt desmito normālaptieku Daugavpilī izteica vēl trīs citi pretendenti: provizors Arturs Hāks, provizors Venceslavs Golubko un provizors Berka Libermans. Ārstniecības noda|a sanēma kategoriskus protestus no visiem deviniiem Daugavpils aptieku īpašniekiem, un desmitās aptiekas atvēršana tika atlikta. Kad B. Libermans nerimās un sūdzējā̄s pat impērijas Senātā, tika paskaidrots, ka Daugavpilī ir tikai 65 tūkstoši iedzīvotāju, bet likums paredz jaunu aptieku apriṇka pilsētā atvērt pēc normatīva - ne mazāk kā 7 tūkstoši iedzīvotāju uz vienu aptiekư ${ }^{48}$.

Aptieku personāla izglîtỉbas līmenis atbilda tradicionālam trīspakāpju dalījumam aptiekas māceklis, aptiekāra palīgs un provizors. Aptiekāra palīga tiesỉbas tika iegūtas pẽc aptiekāru skolas pabeigšanas un eksāmena nolikšanas pie kādas no Krievijas universitātēm. Sekoja kondituēšanās periods un studijas universitātē, noslēgumā iegūstot provizora diplomu. Veicot pētniecỉbu un aizstâvot disertāciju, vēl bijja iespējams iegūt augstāko - farmācijas maǵistra - grādu. Likums paredzēja, ka normālaptieka jāvada provizoram, bet, ja īpašnieks bija kāds cits, tad provizoram jābūt aptiekas pārvaldniekam. Lauku aptiekās tika piejauts, ka provizora vietā tās varētu vadît arī aptiekāra palīgs. Latgales aptiekas šim prasỉbām visumā atbilda, proti, vismaz formāli tās tika ievērotas. Augstāko - farmācijas magistra - grādu bija ieguvuši pieci Latgales aptiekāri. No viṇiem pazīstamākais bija Melhiors Kubli, kas dzimis 1836. gadā Tērbatas apkaimē. Viṇš bija Tērbatas universitātes audzēknis, kur kādu laiku tika strādājis pazīstamā ķīmiķa Kārla Šmita (1822-1894) vadībā un 1865. gadā aizstâvējis farmâcijas mag̀istra disertāciju, pēc tam līdz 1869. gadam turpat bijis privātdocents ${ }^{49}$. No 1873. līdz 1882. gadam M. Kubli bija Daugavpils kara hospitāja aptiekas pārvaldnieks. Hospitālis cietokšņa teritorijā tika uzcelts 1827. gadā, pie reizes tur ierikojot aptieku, ko M. Kubli papildināja ar laboratoriju pētnieciskiem nolūkiem. Šai laikā vinšs publicēja pētijumu par Krāslavas minerālavota ūdens ḳīmisko sastāvu ${ }^{50}$. Vēlāk M. Kubli strādāja Kijevā, publicēja virkni pētījumu un sekmēja armijas sanitārā stāvokja uzlabošanu. Miris 1919. gadā Kijevā ${ }^{51}$.

46 Turpat, 120.1., 2., 5., 29., 30. lp.

47 Turpat, 157. 1., 49., 53. lp.

48 Turpat, 370. 1., 1., 4., 5., 34., 41., 45., 56. 1p.

49 Левицкий Г. В. (ред.) Биографический словарь профессоров и преподавателей Императорского Юрьевского, бывшего Дерптского университета за сто лет его существования (1802-1902). - Юрьев, 1903. - Т. 2. - С. 246,247; Lichinger F. Aus Russlands pharmazeutischer Vergangenheit. - Riga, 1927. - S. 376-378.

50 Кубли М. Исследование воды минерального источника близ Креславки // Фармацевтический Журнал. - 1885. - № 20. - С. 305-308.

${ }^{51}$ Deutsche Apotheker-Biographien. - Stuttgart, 1975. - Bd. 1. - S. 348. 
Savukārt Eduards Keislers dzimis 1851. gadā Vidzemē. 1879. gadā viṇ̌ Tērbatas universitātē aizstāvēja mag̀istra disertāciju, par ko saṇēma zelta meda|u, no 1880 . līdz 1885. gadam strādāja par Rīgas Politehnikuma asistentu un tiesu kīimijas privātdocentu ${ }^{52}$, bet 1883 . gadā atvēra un drīz pẽc tam pārdeva Aleksandra aptieku Rīgā. Vēlāk E. Keislers neilgu laiku bija Gostiṇu aptiekas părvaldnieks, bet turpmāk saimniekoja savā zemesīpašumā ${ }^{53}$.

Trešais mag̉istrs, Jāns Juts, dzimis 1865. gadā Pērnavas aprinḳī, disertāciju aizstāvēja Tērbatā 1894. gadā ${ }^{54}$. Apmeties Daugavpilī, viṇš sākumā bija aptiekas părvaldnieks, vēlāk - īpašnieks, izveidojot to par priekšzīmīgāko aptieku pilsētā, ko papildināja ar plašu kīimisko laboratoriju, mākslīgo minerālūdeṇu ražotni un zinātnisko bibliotēku. Ipaši nozīmīga J. Juta aptiekas un laboratorijas darbība bija Pirmā pasaules kara laikā, kad viṇš sāka ražot serumus un vakcīnas armijas vajadżỉbām. Sarkanā terora laikā 1919. gadā J. Juts tika arestêts un ievietots cietumā, bet aptieka - nacionalizēta un sagrauta. Pēc tam J. Juts aptieku vairs neatjaunoja, turpinot darbu tikai laboratorijā. Būdams igaunis, vịňs rosīgi darbojās Daugavpils Latviešu biedrỉbā un pilsētas Domē, kādu laiku būdams tās priekšsēdētājs ${ }^{55}$. J. Juts miris 1930. gadā Daugavpilī, apbedîts Tērbatāân Par atlikušajiem diviem magistriem dati ir fragmentāri. Oskars Lēventāls disertāciju aizstāvēja 1868. gadā Kara medicīnas akadēmijā Sanktpēterburgā ${ }^{57}$; ap 1874. gadu strādāja Daugavpilī, vēlāk - Maskavā. Bet Leiba Levitess, kas pirms Pirmā pasaules kara strādāja Krustpilī un vēlāk Jaunjelgavā, maǵistra disertāciju bija aizstāvējis Tērbatā 1899. gadā ${ }^{58}$.

Vairāki vietējie aptiekāri kopā ar ārstiem un veterinārărstiem piedalījās Latgalē vienīgās Daugavpils Medicīnas biedrỉbas darbā, kura dibināta 1882. gadā $^{59}$, taču tẫs sēdēs farmācijas jautājumiem tika pievērsts maz vērỉbas.

Vairākums Latgales aptiekāru bija tuvējās Tērbatas universitātes audzēkṇi, lai gan tika pārstāvēti arī citi zinātnes un augstskolu centri - Maskava, Pēterburga, Varšava u. c. Pēc

52 Album Academicum Рижского Политехнического института: 1862-1912. Рига, 1912. - С. 701.

53 Lichinger F. Die Geschichte der Pharmazeutischen Gesellschaft zu Riga. - Riga, 1903. - S. 84,85.

54 Tartu Ûlikooli üliōpilaskomna teatmik: 1889-1918. - Tartu, 1986. - Lk. 30.

55 Jāña Jutta piemiṇai // Latgales Zinas. - 1930. - 7. marts.

56 Jānis Jutts // Latgales Zinas. - 1930. - 28. febr.

57 Ткешелашвили М. С. Материалы для истории фармации в России: Биографический словарь фармацевтов, получивших степень магистра фармации. - Москва, 1901. - С. 47.

58 Tartu Ülikooli arstiteaduskonnas 1892-1917 kaistud väitekirjad. - Tartu, 1965. - Lk. 25.

59 Протоколы заседаний Динабургского медицинского общества за 1882/83 годы. - Динабург, 1884. 


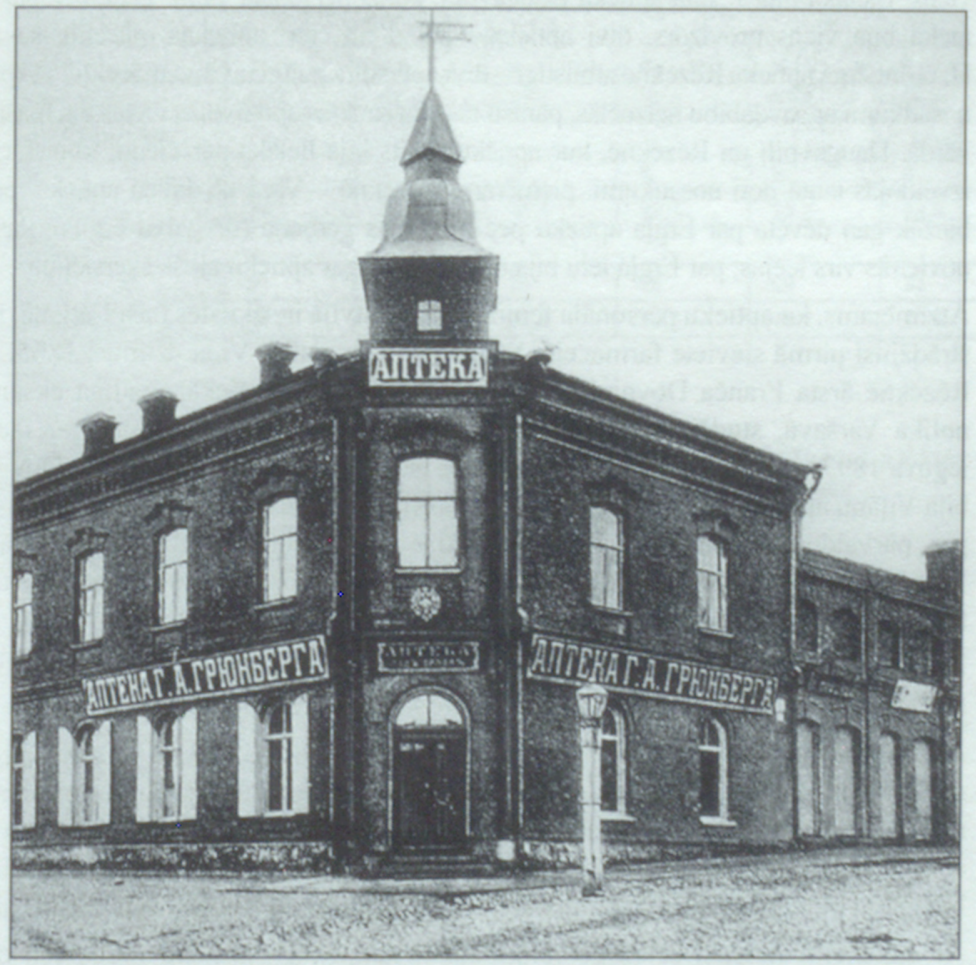

Rẽzeknes Êrg|a aptiekas ēka 1908. gadā 
nacionālās piederỉbas sākumā lielākoties aptieku îpašnieki bija vācieši (vācbaltieši), taču vinu īpatsvars pakāpeniski mazinājās, jo aptiekas vadīja arī poli un krievi, bet no 19. gs. otrās puses - aizvien vairāk ebreji, kas 20. gs. sākumā jau dominēja. Latviešu īpatsvars bija neliels. 1914. gadā starp Latgales aptieku pārvaldniekiem bija 17 ebreji, septiṇi vācieši, trīs poḷi, trīs latvieši un pa vienam lietuvietim un igaunim ${ }^{60}$.

Aptiekas bija nelielas, tajās strādāja pāris darbinieku, bet lauku aptiekās it bieži - tikai viens. Lielākā bija J. Juta aptieka Daugavpilī, kuras personālā 1914. gadā bez pārvaldnieka bija viens provizors, divi aptiekāra palīgi un četri aptiekas mãcekḷi, savukārt H. Grīnberga aptiekā Rēzeknē atbilstīgi-divi aptiekāra palīgi un divi mācek|i ${ }^{61}$. Aptieku nosaukumi ar savdabỉbu neizcēlās, parasti tâs tika sauktas apdzīvotās vietas vai īpašnieka vārdā. Daugavpilī un Rēzeknē, kur aptieku skaits bija lielāks par vienu, to atšķiršanai izveidojâs tautā doti nosaukumi, piemēram, Rēzeknē - Vecā un Jaunā aptieka, pēdējā biežāk gan dēvēta par Êrgla aptieku pēc impērijas gerboṇa (divgalvu êrglis), kas bija novietots virs ieejas; par Ērgla ielu bija nosaukta arī gar aptieku ejošā šķērsieliņa.

Atzīmējams, ka aptieku personāla feminizācija Latvijā ir sākusies tieši Latgalē, jo tur strādājusi pirmā sieviete farmaceite Staņislava Dovgjallo. Viṇa dzimusi 1865. gadā Rēzeknē ārsta Franča Dovgjallo (1815-1887) ġimenē, aptiekăra palīga eksāmenu nolika Varšavā, studēja Krakovas universitātē, bet provizora diplomu ar izcilību ieguva 1897. gadā Maskavas universitātế62. No 1897. līdz 1906. gadam S. Dovgjallo bija Vilānu aptiekas īpašniece. Šajā laikā, proti, no 1901. līdz 1906. gadam, pie viṇas par pārvaldnieci strādāja aptiekāra palīdze Jelizaveta Busurmanova. Vēelāk S. Dovgjallo bija izglītỉbas, kultūras un sabiedriskā darbiniece Rēzeknē, piedalījās politiskā ciṇ̄ā, bet mūža nogalē devās uz Krakovu, kur mirusi 1933. gadā.

Aptieku skaita pieaugums un iedzīvotāju aptveramība Latgalē skaitliski raksturota 1. tabulā, bet salīdzinoši dati par Latviju kopumā ietverti 2. tabulā.

Aptieku ierīkojums un darba kārtība bija tradicionāla, savam laikmetam atbilstī$\mathrm{ga}^{64}$, tâlab Šeit detalizētāk netiek aplūkota. Aptiekām piemita privātīpašniecisks raksturs ar no tā izrietošām sekām; komunālo aptieku Latgalē vēl nebija, un tikai divas (abas Daugavpilī) aptiekas piederêja nevalstiskām organizācijām - Dzelzce|a kalpotāju patērētāju biedrỉbai un Ebreju trūcīgo slimnieku palīdzības biedrībai.

Ar aptiekām diezgan sekmīgi konkurēja lielāks skaits aptieku preču jeb drogu veikalu. Tirgojoties ar ierobežota sortimenta precēm, tãs aptieku īpašnieku vidū

\footnotetext{
60 Российский медицинский список на 1914 год. - СПб., 1914. - С. 16-18.

61 Turpat.

62 Pabis-Braunstein M. The First Polish Women Pharmacists // Pharmacy in History. - 1989. - № 1. - P. 12-15.

63 Виксна А. А. История аптечного дела в Латгалии (1772-1917) // Изыскания в области фармации. - Рига, 1977. - С. 25-29.

64 Vīksna $A$. Vecãs aptiekas. - Rīga, 1993. - 160 lpp.
} 
1. tabula. Latgales aptieku skaits un iedzīvotāju skaits (tūkstošos) uz vienu aptieku no 1848. līdz 1914. gadam

\begin{tabular}{|c|c|c|c|c|c|c|}
\hline Gads & 1848 & 1864 & 1886 & 1897 & 1905 & 1914 \\
\hline \multicolumn{7}{|c|}{ Daugavpils aprinkis } \\
\hline Skaits & 2 & 4 & 15 & 16 & 18 & 21 \\
\hline Uz 1 aptieku & 38,8 & 34,5 & 14,3 & 14,8 & 14,0 & 14,9 \\
\hline \multicolumn{7}{|c|}{ Ludzas aprinkis } \\
\hline Skaits & 1 & 1 & 2 & 4 & 5 & 6 \\
\hline Uz 1 aptieku & 63,4 & 68,0 & 51,3 & 32,0 & 22,7 & 26,6 \\
\hline \multicolumn{7}{|c|}{ Rêzeknes aprinkisis } \\
\hline Skaits & 2 & 2 & 3 & 6 & 6 & 6 \\
\hline Uz 1 aptieku & 37,1 & 43,7 & 42,4 & 22,7 & 25,2 & 28,9 \\
\hline \multicolumn{7}{|l|}{ Latgale } \\
\hline Skaits & 5 & 7 & 20 & 26 & 29 & 33 \\
\hline Uz 1 aptieku & 43,0 & 41,9 & 22,2 & 19,3 & 18.5 & 19.6 \\
\hline
\end{tabular}

\section{2. tabula. Latvijas aptieku skaits un iedzĩvotāju skaits (tūkstošos) uz vienu} aptieku 19. gs. beigās un pirms Pirmã pasaules kara ${ }^{63}$

\begin{tabular}{|l|l|l|l|l|}
\hline \multirow{2}{*}{ Novads } & 1897. gadă & 1914. gadă \\
\cline { 2 - 5 } & Skaits & Uz 1 aptieku & Skaits & Uz 1 aptieku \\
\hline Kurzeme & 83 & 8,1 & 98 & 8,6 \\
\hline Vidzeme & 102 & 7,4 & 132 & 8,4 \\
\hline Latgale & 26 & 19,3 & 33 & 19,6 \\
\hline Latvija & 211 & 9,1 & 258 & 9,9 \\
\hline
\end{tabular}

izraisīja pastāvīgu nepatiku, noniecinājumu un mēginājumus ierobežot šo nevēlamo konkurentu darbību, kas arī vismaz da|ēji izdevãs. Lūk, kāds bija oficiālās varas pārstāvju viedoklis 1914. gadā: šie aptieku preču veikali ir “...liels launums, ar ko nākas nemitīgi cīnîties, lai tos kaut necik piespiestu cienüt un ievêrot likumã noteikto kārtību. Bez tam, veikalu personāls ir galīgi neizglìtots, bez kādas sajēgas par farmāciju" 65 .

Pirms Pirmā pasaules kara sākuma 1914. gadã Latgalē bija izveidojies šāds aptieku tîkls: Daugavpils aprinkịi - 12 aptiekas Daugavpilī, kã arī Dagdā, Gostiṇos, Krāslavā, Krustpilī, Lĩvānos, Pogu|ankā, Prei|los, Stropos un Višķos; Ludzas apriṇḳī - aptiekas

65 Обзор Витебской губернии за 1914 год. - Витебск, 1916. - С. 39. 
Baltinavā, Balvos, Kārsavā, Ludzā, Vilakā un Zilupē, Rēzeknes apriṇkī - divas aptiekas Rēzeknē un pa vienai Riebinos, Stalidzānos, Varak|ānos un Vị̣ānos ${ }^{66}$. Dalījums pēc aptiekas tipa: 23 normālaptiekas, astoṇas lauku aptiekas (Baltinavā, Balvos, Riebiṇos, Stalidzānos, Viḷakā, Vị̄ānos, Viškşos, Zilupē) un divas filiālaptiekas vasaras laikā (Pogulankā, Stropos).

Kopumā nemot, Latgales aptieku tỉkls, kas izveidojâs 19. gs. sākumā, turpmākā gadsimta gaitā piedzīvoja kāpumu un pietiekami plašu izvērsumu, gan pagaidām atpaliekot no pārējiem Latvijas novadiem. Latgales aptieku turpmākās gaitas pētniecỉba vairs neizraisa nopietnākus sarežg̀ijumus, jo dati ir pieejami gan dalējii publicētā, gan arī visai pilnīgi saglabātu dokumentu veidā, piemēram, ikvienas aptiekas lieta par darbību laikposmā no 1920. līdz 1944. gadam atrodama Farmācijas pārvaldes fondā Latvijas Valsts vêstures arhīvā ${ }^{67}$. Pētnieciskā darba turpinājumā padzilinātai un rüpīgai izpētei pakłaujams tieši Latgales aptieku agrīnais posms, to pirmā parādīšanās un tapšana laikā pirms 19. gs., kur sagaidāmi vēl jauni atklājumi un konstatẹjumi.

Pielikums. Latgales aptieku īpašnieku un pārvaldnieku hronologiisks saraksts no 1864. līdz 1914. gadam

Sarakstu veidojot, par pamatu izmantots ikgadējs oficiāls izdevums Российский медицинский список, kas iznāca no 1809. līdz 1916. gadam un kopš 1864. gada ietvēra datus par aptiekām, aptieku īpašniekiem un pārvaldniekiem: uzvārds, vārds, tēvavārds (reizẽm nepilnīgi), izglîtības līmenis, kopš 1890. gada - arī tautỉba un konfesionālā piederỉba. Publicētie dati varētu būt nedaudz neprecīzi (stāvokla izmaiņas saraksta sagatavošanas un publicēšanas gaitā; ierēdņu inerce, atkărtojot iepriekš̌ējo), tomēr kopēju priekšstatu tie rada. Aptiekas dibināšanas laiks (pirmoreiz minēta sarakstā) varētu būt nedaudz atš̌kirīgs, jo at|aujas saṇemšana, darbības uzsākšana un ietveršana oficiālā sarakstā nenotika vienlaikus. Precizējumi izdarīi gadijjumos, ja arhīva vai publicētos dokumentos izdevās atrast konkrētāku norādi par dibināšanu, bet salīdzinājumam izmantots V. Eihenbauma un D. Slukas apkopojums ${ }^{68}$.

Turpmāk publicētā sarakstā aptiekas kārtotas pilsētu vai apdzīvoto vietu alfabētiskā secībā, bet vienas pilsētas ietvaros - dibināšanas secỉbā. Norādīti katras aptiekas īpašnieki un pārvaldnieki hronologiskā secībā, bet gadījumos, ja īpašnieks vienlaikus ir bijis arī pārvaldnieks, pēdējais izlaists. Par laiku pēc 1914. gada norādīts tikai aptiekas turpmākais liktenis - slēgta vai darbojas līdz mūsu dienām.

66 Памятная книжка Витебской губернии на 1914 год. - Витебск, 1914. - С. $164,206,248$.

67 LVVA, 4958. f.

68 Eihenbaums $V$, Sluka D. Latvijas Farmācijas enciklopēdijas šķirkju saraksts: Latvijas aptiekas 1357-1999 (bez Rīgas) // Aptiekas gadagrāmata 1999. - Rīga, 1999. - 5. -89. Ipp. 
Saīsinājumi: apt. māc. - aptiekas māceklis, apt. pal. - aptiekāra palīgs, farm. maǵ.

- farmācijas mag̀istrs, īp. - īpašnieks, pārv. - pārvaldnieks, prov. - provizors.

\section{Baltinava}

1910-1913 īp. sîkpilsonis B. Gutins,

pārv. 1910-1911 apt. pal. Vulfs Macs,

pārv. 1912-1913 apt. pal. Icko Rubenčiks;

1914-1914 īp. apt. māc. Jānis Krakops.

Darbību mūsu dienās turpina kā Žeikaru aptieka Slimnīcas ielā 5.

\section{Balvi}

1899-1914 īp. prov. Pāvels Lavrinovičs,

pārv. 1912 prov. Heinrihs Meiers,

pārv. 1913 apt. pal. Gustavs Hermanis,

pārv. 1914 apt. pal. Zīmels Aizenštats.

Aptieka slēgta 1939. gadā, pēdējā adrese - Bērzpils ielă 12. 1934. gadā Rīgas ielā 10 ierīkota Jaunā aptieka, kas slēgta 1944. gadā, bet 1935. gadā - Pilsētas aptieka, kas mūsu dienās darbību turpina Rīgas ielā 6.

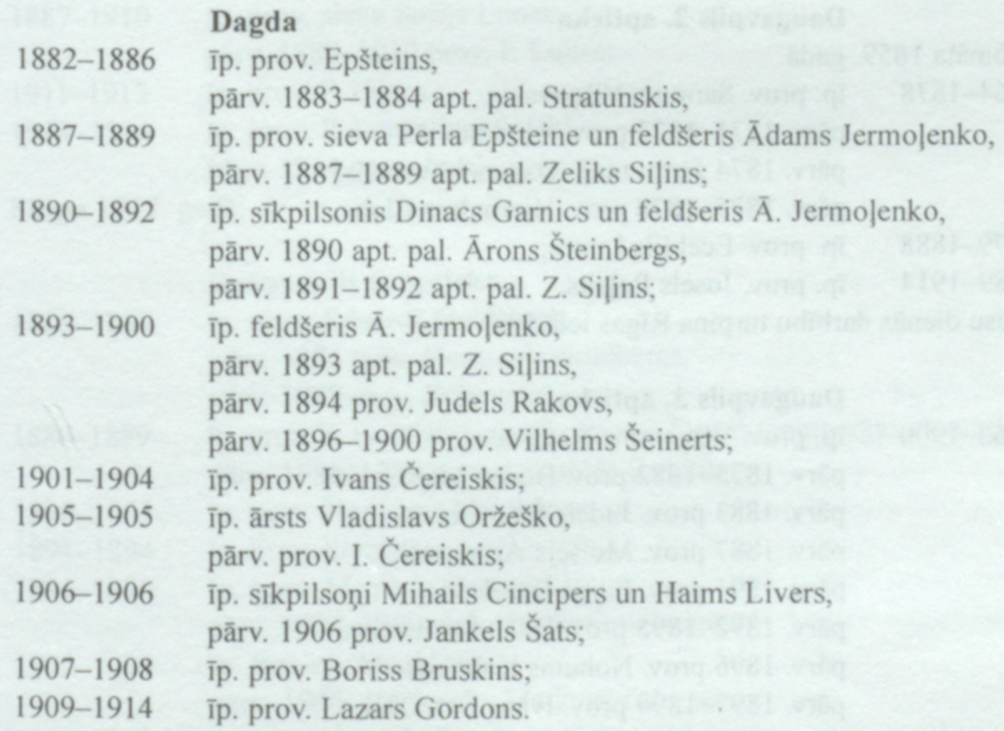

Darbỉbu kā Vecā aptieka Asūnes ielā 9 pārtraukusi 1941. gadā, kad pievienota 1931. gadā dibinātai Jaunai aptiekai Alejas ielā 19. 


\section{Daugavpils 1. aptieka}

Dibināta vai darbību atjaunojusi 1818, gadā.

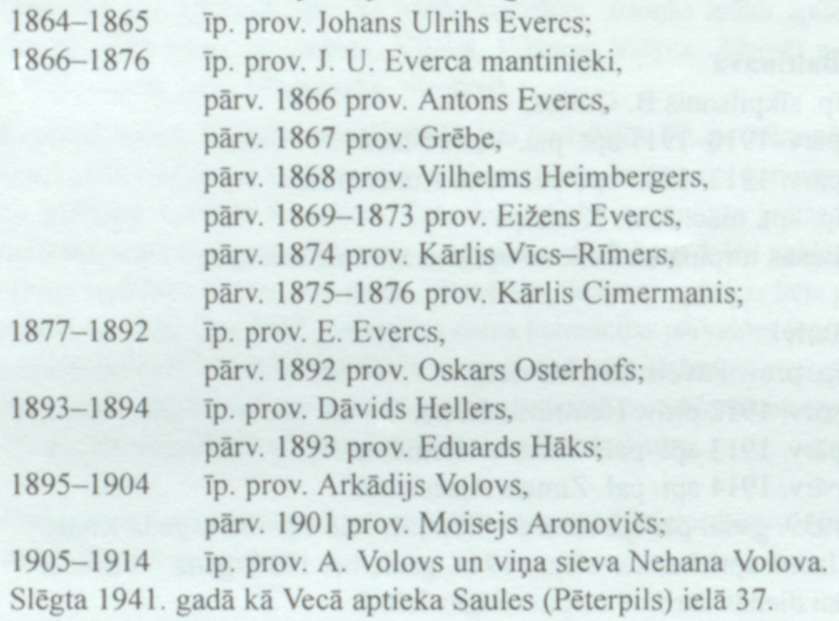

\section{Daugavpils 2. aptieka}

Dibināta 1859. gadā.
1864-1878 īp. prov. Samuils Višnavskis, pārv. 1871-1873 prov. Abramovičs, pārv. 1874 farm. mag̀. Oskars Lēventāls, pārv. 1875-1878 prov. Hieronīms Blohs,
1879-1888 īp. prov. Ecehiils Luncs;
1889-1914 īp. prov. Josels Polaks.
Mũsu dienās darbỉbu turpina Rīgas ielā 54a.

1865-1900 īp. prov. Venjamins Natansons, pārv. 1875-1882 prov. Boriss Manaseviěs, pārv. 1883 prov. Judels Šternšteins, părv. 1887 prov. Moisejs Aronoviěs, pārv. 1891 prov. Filips Izraelsons, pārv. 1892-1895 prov. Izāks Šternšteins, pārv. 1896 prov. Nohums Kabaks, pārv. 1897-1899 prov. Ivans Čereiskis, pārv. 1900 prov. Kivels Kagans;

1901-1908 īp. prov. Bencels Kramniks, părv. 1908 prov. Faivišs Kacins; 
1909-1914 īp. prov. F. Kacins un viña sieva Hiena Kacina.

Slēgta 1940. gadā kā Kacina aptieka Cietokšña (Maskavas) ielā 49.

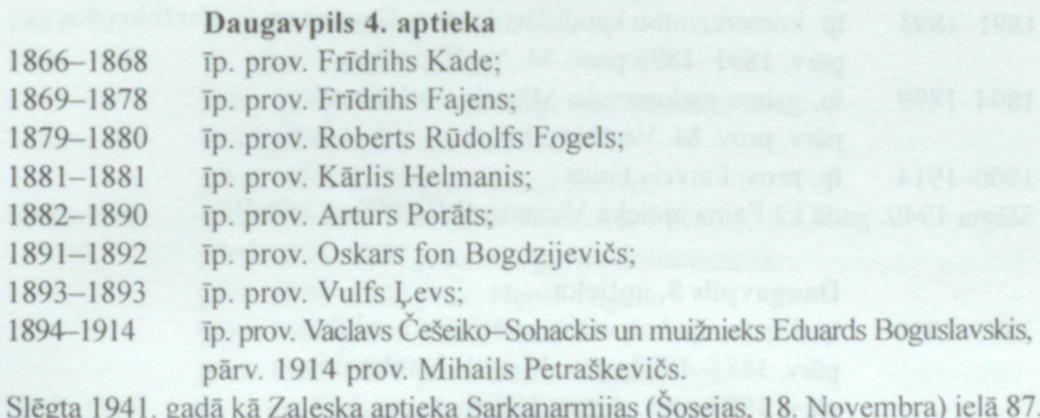

\section{Daugavpils 5. aptieka}

1870-1884 îp. prov. Ecehiils Luncs ;

1885-1886 īp. prov. I. Šlēzingers, pārv. 1886 prov. Pauls Luncs;

1887-1910 īp. prov. sieva Sofija Lunca, pārv. 1887-1910 prov. P. Luncs;

1911-1913 îp. prov. P. Luncs ;

1914-1914 īp. prov. P. Lunca mantinieki, pārv. 1914 prov. Josels Šohers.

Slēgta 1917. gadā.

Daugavpils 6. aptieka

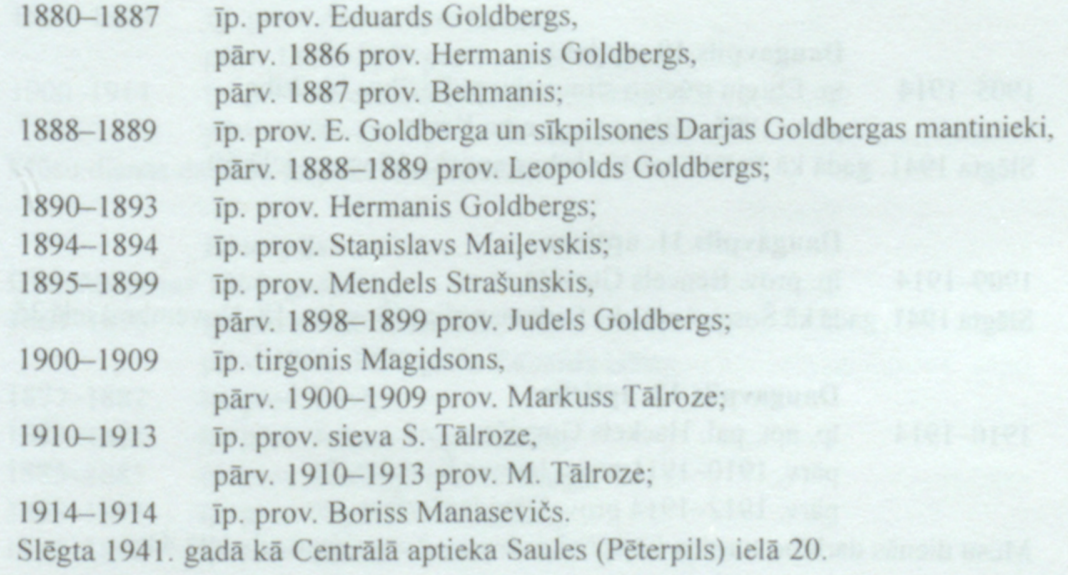




\begin{tabular}{ll}
\multirow{2}{1}{$1882-1890$} & $\begin{array}{l}\text { Daugavpils 7. aptieka } \\
\text { ip. Sofija Veržblovska, } \\
\text { prov. } 1882-1890 \text { prov. Mihails Veržblovskis; }\end{array}$ \\
$1891-1893$ & $\begin{array}{l}\text { ip. komerczinību kandidāts Izidors Gecovs un S. Veržblovska, } \\
\text { pārv. } 1891-1893 \text { prov. M. Veržblovskis; }\end{array}$ \\
$1894-1899$ & $\begin{array}{l}\text { ip. galma padomnieks Mihails Berkmans, } \\
\text { pārv. prov. M. Veržblovskis; }\end{array}$ \\
$1900-1914$ & $\begin{array}{l}\text { ip. prov. Faivels Fains. } \\
\text { ing }\end{array}$
\end{tabular}

Slēgta 1940. gadā kā Faina aptieka Viestura (Miesnieku) ielā 40.

1885-1910 īp. Dzelzce|a kalpotāju patērētāju biedrība, pârv. 1885-1903 prov. Mihails Karčevskis, pārv. 1904 prov. Arturs Hāks, pārv. 1905-1910 prov. Ivans Kuṇevičs;

1911-1914 īp. prov. I. Kuneviěs.

Slēgta 1942. gadā kã Zaleska aptieka Raiņa (Muižnieku) ielā 107.

\section{Daugavpils 9. aptieka}

1892-1893 ip. prov. Ivans Čereiskis;

1894-1895 īp. prov. Josifs Lukaševičs;

1896-1897 īp. prov. Oto Dipners,

pārv. 1896-1897 farm. mag̀. Jāns Juts;

1898-1910 īp. Klāra fon Kehere,

pārv. 1898-1910 farm. mag̀. J. Juts;

1911-1914 î̀. farm. mag. J. Juts.

Slēgta 1919. gadā.

\section{Daugavpils 10. aptieka}

1905-1914 īp. Ebreju trūcīgo slimnieku palīdzības biedrība, pārv. 1905-1914 prov. Leiba Krols.

Slēgta 1941. gadā kã Palīdzības biedrïbas aptieka Viestura ielā 60.

1909-1914 īp. prov. Bencels Gurvičs.

Slēgta 1941. gadā kā Šosejas aptieka Sarkanarmijas (Šosejas, 18. Novembra) ielā 35.

\section{Daugavpils 12. aptieka}

1910-1914 ìp. apt. pal. Hackels Gurvičs,

pārv. 1910-1911 prov. Jakovs Kopeloviěs,

pārv. 1912-1914 prov. Dāvids Čerfass.

Mūsu dienās darbību turpina kā aptieka Arnika Farm Ventspils ielā 41. 


\section{Gostini}

1878-1880 īp. prov. Hieronīms Blohs, pārv. 1879-1880 prov. Johans Alejs;

1881-1889 īp. prov. J. Alejs;

1890-1891 īp. prov. Teodors Klaus,

pārv. 1890-1891 farm. mag̀. Eduards Keislers;

1892-1895 īp.sīkpilsonis Eižens Bevers, pārv. 1892-1895 prov. Jūlijs Krūze;

1896-1902 īp. sīkpilsonis Hermanis Volosovs, pãrv. 1896-1897 prov. Grigorijs Solomonovs, pārv. 1898-1900 prov. Heršs Tāgers, pārv. 1901 prov. Ārons Tecs, pārv. 1902-1903 prov. Leiba Minkovskis;

1903-1912 îp. prov. Sigizmunds Fedorovičs;

1913-1914 ìp. A. Jansons,

pārv. 1913-1914 prov. Gothards Jansons.

Darbību mūsu dienās turpina Plavin̄ās, Lielā ielā 34. (Gostini 1957. gadā pievienoti Plavinām.)

\section{Kārsava}

1883-1903 īp. prov. Semjons Ostrovskis, pārv. 1885-1887 apt. pal. Šohers;

1904-1914 īp. prov. Arturs Vāvers.

Mûsu dienās darbību turpina Vienības ielā 85 .

\section{Krāslava}

Dibinăta 18. gs.

1864-1899 īp. prov. Aleksandrs Bonins, pārv. 1890-1899 prov. Arvēds Bonins;

1900-1914 īp. prov. Aleksandra Bonina mantinieki, pārv. 1900-1914 prov. Arvēds Bonins.

Mūsu dienās darbību turpina Brīvỉbas ielā 8 .

\section{Krustpils}

Dibināta pirms 1864. gada.

1864-1876 īp. prov. Ādolfs Krauze, pārv. 1868-1876 prov. Eduards Nēze;

1877-1882 îp. prov. Levi;

1883-1884 îp. prov. Johans Hugo Klūge;

1885-1885 îp. prov. Nikolajs Meklenburgs;

1888-1891 ip. prov. Samuils Klivanskis;

1892-1892 īp. prov. Kărlis Sanio; 
1893-1909 īp. tirgonis Rivošs,

pārv. 1893-1896 prov. Josifs Rivošs,

pārv. 1897 prov. Lazars Jakubsons,

pārv. 1898-1899 prov. Josifs Sivens,

pārv. 1900-1908 prov. J. Rivošs,

pārv. 1909 prov. Josifs Tecs;

1910-1914 îp. prov. J. Rivošs,

pārv. 1910-1914 farm. mag̀. Leiba Levitess.

Slēgta 1944. gadā, pēdējā adrese - Rĩgas ielā 113. 1929. gadā nodibināta Čamaṇa aptieka, kas mūsu dienās saucas par Krustpils aptieku - Jēkabpilī, Rīgas ielā 141.

\section{Lĩvāni}

1868-1880 īp. prov. Jasinskis, pārv. 1877-1880 prov. Frīdrihs Kade;

1881-1894 īp. prov. F. Kade, pārv. 1894 prov. Zeinholds Švānfelds;

1895-1914 īp. prov. Arturs Frīde, pārv. 1909-1914 prov. Kārlis Kohs.

Slēgta 1941. gadā kā Lielā aptieka Rīgas ielā 184. 1923. gadā dibinātā Centra aptieka darbojas līdz mūsu dienām Rīgas ielā 114.

\section{Ludza}

Dibināta 1818. gadā vai agrāk.

1864-1874 ip. prov. Roberts Bekers;

1875-1880 ip. Bekera kundze, pārv. 1875-1880 prov. Semjons Ostrovskis;

1881-1914 îp. prov. R. Bekera mantinieki, pārv. 1881-1886 prov. S. Ostrovskis, pārv. 1887 prov. Leonīds Georgs, părv. 1888-1914 prov. Roberts Bekers jun.

Mũsu dienās darbību turpina kā Centra aptieka Stacijas ielā 49/1.

\section{Pasiene}

1890-1901 ìp. apt. pal. Movša Gošteins, pārv. 1898-1901 apt. pal. Kārlis Millers.

Slēgta 1901. gadā. No jauna aptieka Pasienē atvērta 1923. gadā un slēgta 1944. gadā. Vēlreiz atvērta 1955, gadā un 1993, gadā.

\section{Pogulanka}

1901-1914 īp. prov. Vaclavs Češeiko-Sohackis, pārv. 1901-1903 apt. pal. Stepans Antonoviěs, pārv. 1904-1905 apt. pal. Stanislavs Vēbers, 
pārv. 1906 apt. pal. V. Klopotovskis,

pārv. 1911 apt. pal. Oskars Jansons,

pārv. 1912 apt. pal. S. Labacevičs,

părv. 1913-1914 apt. pal. Staņislavs Sikorskis.

Slēgta 1917. gadā. (Pogu|anka 1937. gadā pārdēvēta par Mežciemu, kas 1946. gadā iek|auts Daugavpils pilsētas teritorijā.)

\section{Preili}

1880-1890 îp. prov. Hugo Šteins,

pārv. 1887-1890 prov. Aleksandrs Ritenbergs;

1891-1900 īp. prov. A. Ritenbergs;

1901-1903 īp. prov. Pēteris Matvejs;

1904-1905 îp. prov. Vilhelms Helds;

1906-1914 îp. prov. V. Helda mantinieki,

părv. 1906 apt. pal. Rūdolfs Benings,

pārv. 1907 apt. pal. K. Reimanis,

pārv. 1908-1913 prov. Alberts Klingenbergs,

pārv. 1914 prov. Juris Pulkovskis.

Slēgta 1939. gadā kā Pirmā aptieka Raina bulv. 3, kad jau no 1927. gada darbojās Centrālā aptieka, kas pastāv līdz mūsu dienām Raiṇa bulv. 5.

\section{Rēzekne, 1. aptieka}

Dibināta pirms 1836. gada.

1864-1876 īp. prov. Kārlis Lucavs,

pārv. 1876 prov. Aleksandrs Hāgetorns;

1877-1877 īp. prov. K. Lucava mantinieki, pārv. 1877 prov. Alfreds Šūmanis;

1878-1878 īp. prov. Johans Hugo Klūge;

1879-1879 îp. tirgone Frīdberga, pārv. 1879 prov. Šilanskis;

1880-1881 īp. prov. Šilanskis, pārv. 1880-1881 prov. Izrails Luncs;

1882-1889 īp. prov. I. Luncs;

1890-1913 îp. prov. Žanno Jēgermanis;

1914-1914 īp. prov. Meilihs Paperna.

Slēgta 1944. gadā kā Vecā aptieka Atbrīvošanas alejā 25.

1882-1884 īp. prov. G. Šlēzingers;

1885-1893 īp. sīkpilsonis Volfs Ditkovskis, pārv. 1885 prov. G. Šlēzingers, părv. 1886-1889 prov. Solomons Janovskis, 
părv. 1890-1893 prov. Izidors Luncs;

1894-1895 īp. prov. Kivs Lurjē, pārv. 1895 prov. Hugo Grīnbergs;

1895-1914 īp. prov. H. Grīnbergs, pårv. 1911 prov. Dāvids Čerfass.

Mūsu dienās turpina darbỉbu kā Êrg|a aptieka Latgales ielā 41. Pie ēkas1997. gadã piestiprinăta piemiņas plāksne aptiekai.

\section{Riebiñi}

1896-1899 īp. muižnieks Nikolajs Koreckis, pãrv. 1896-1899 apt. pal. Elija Havesons;

1900-1913 īp. apt. pal. E. Havesons, pārv. 1902 apt. pal. Sofija Rabinoviča;

1914-1914 īp. apt. pal. Mendels Mednikovs.

Slēgta 1941. gadā.

\section{Stalidzāni}

1892-1897 īp. apt. pal. Johans Rozenšteins;

1898-1914 ìp. ārsts Augusts Blaus, părv. 1898 apt. pal. J. Rozenšteins, părv. 1899-1910 apt. pal. Georgs Konradi, pārv. 1911 apt. pal. Nikolajs Madernieks, pārv. 1912-1914 apt. pal. Kārlis Videnieks.

Slēgta 1916. gadā.

\section{Stropi}

1910-1914 ìp. prov. Faivels Fains, părv. 1910-1911 apt. pal. Iciks Faibs, pārv. 1912 apt. pal. Dibobess, părv. 1913 apt. pal. Z. Cins, pārv. 1914 apt. pal. Notels Blohs.

Slēgta Pirmā pasaules kara laikā, atjaunota 1929. gadā, darbojusies līdz 1939. gadam.

\section{Varakłāni}

Dibināta 1828. gadā vai agrāk.

1864-1895 î̀p. grāfs Kārlis Borhs un viña mantinieki, părv. 1864-1895 prov. Leopolds Hāgemanis;

1896-1898 īp. prov. L. Hāgemanis, părv. 1898 prov. Voldemãrs Hāgemanis;

1899-1899 īp. prov. L. Hāgemaṇa mantinieki, pãrv. 1899 prov. V. Hāgemanis;

1900-1903 îp. prov. Konstantīns Baumanis; 
1904-1914 īp. prov. Ferdinands Ekmanis.

Darbību mūsu dienās turpina kā aptieka Alianse Rīgas ielā 13.

\section{Vilaka}

1894-1914 īp. apt. pal. Ignācijs Rahunkovičs.

Mūsu dienās darbību turpina Abrenes ielā 3.

\section{Vilāni}

1887-1891 īp. sīkpilsonis Meiers Bernšteins, pārv. 1888-1889 apt. pal. Josifs Godlevskis, pārv. 1890 apt. pal. Mendels Berelsons, pārv. 1891 apt. pal. Matvejs Pukeñevskis;

1892-1897 īp. tirgonis Nosens Edelšteins, pārv. 1892 apt. pal. M. Pukenevskis, pārv. 1893-1894 prov. Jakovs Merkovs, pārv. 1895-1896 apt. pal. Romāns Stencels, pārv. 1897 apt. pal. Daniils Sobickis, pãrv. 1897 apt. pal. Ivans Jodkovskis;

1897-1906 īp. prov. Stanislava Dovgjallo, pārv. 1901-1906 apt. pal. Jeļizaveta Busurmanova;

1907-1913 īp. apt. pal. G. Fogels, pārv. 1907 apt. pal. Hanss Čižs, pārv. 1908 apt. pal. K. Jesbergs, pārv. 1909-1913 apt. pal. Aleksandrs Kordts;

1914-1914 īp. apt. pal. Leo Birkhans.

Mūsu dienās darbību turpina Kultūras lauk. 4.

\section{Viški}

1883-1892 īp. apt. pal. Kārlis Šmits, pārv. 1887 apt. pal. V. Fukss, pārv. 1888 apt. pal. Kārlis Geršners;

1893-1896 īp. apt. pal. sieva Karolīne Šmite, pårv. 1893-1894 apt. pal. Semjons Pinuss, pārv. 1895-1896 apt. pal. Leonhards Zuments, pārv. 1895-1903 apt. pal. L. Zuments;

1897-1903 īp. apt. pal. sieva Karolīne Zumente, pårv. 1897-1903 apt. pal. L. Zuments;

1904-1914 īp. apt. pal. L. Zuments.

Darbību turpina mūsu dienâs. 


\section{Zilupe}

1903-1909 īp. prov. Edgars Mērholds, pārv. 1906 apt. pal. Alfons Zakss;

1910-1910 īp. apt. pal. Leo Pētersons, pārv. 1910 prov. Pēteris Kathins;

1911-1911 î̀. sîkpilsonis Š. Misulavins, pãrv. 1911 apt. pal. L. Pētersons;

1912-1912 īp. apt. pal. L. Pētersons, pārv. 1912 apt. pal. Jekels Gurviěs;

1913-1914 ìp. prov. Suzanna Zakse, pārv. 1914 apt. pal. Haims Zakss.

Turpina darbību līdz mūsu dienām Brīvỉbas ielā 11.

Pateicība. Par konsultatĩvu palīdzību raksta tapšanas gaitā pateicos Krāslavas Vēstures un mākslas muzeja krājuma glabātājai Annai Jermakovai un Paula Stradiṇa Medicīnas vēstures muzeja līdzstrādniecei Janīnai Danusēvičai.

\section{The Beginnings of Drug-stores in Latgale (Summary)}

By Arnis Viksna

Based of documents from archives and the published literature, an attempt has been made to describe data concerning the rise of drug-shops in Latgale and their activities since the $18^{\text {th }}$ century and up to World War I. Biographical data are given about pharmaceutical magisters M. Kubli (1836-1919), J. Juta (1865-1930), the first woman pharmacist in Latvia S. Dovgjallo (1865-1933) and others. Although there was an increase of pharmacies from 3 in 1821 to 33 in 1914, there were fewer of them than in the rest of Latvia's territory. An appendix is added containing data about the owners and supervisors of pharmacies in Latgale from 1864 to 1914.

Arnis Vīksna, Dr. habil. med., prof., LZA akad.

LU Medicīnas fakultāte

Raina bulv. 19

Rīga LV-1586, Latvija 